\title{
The ramification of Arabic gum and gelatine incorporation on the physicochemical properties of Belimbing Buluh (Averhoa belimbi) fruits pastilles
}

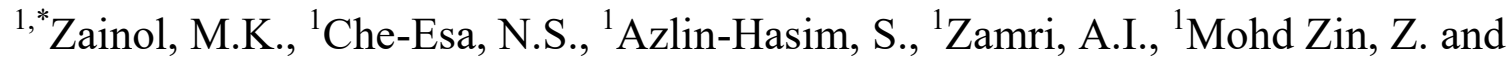 \\ ${ }^{2}$ Abdul Majid, H.A. \\ ${ }^{1}$ Faculty of Fisheries and Food Sciences, Universiti Malaysia Terengganu, 21030, Kuala Nerus, \\ Terengganu, Malaysia \\ ${ }^{2}$ Universiti Teknologi MARA Terengganu Branch, Kampus Kuala Terengganu, 21080 Kuala Terengganu, \\ Terengganu, Malaysia
}

\begin{abstract}
Article history:
Received: 29 September 2019

Received in revised form: 10

November 2019

Accepted: 12 November 2019

Available Online: 9

December 2019
\end{abstract}

Keywords:

Averhoa belimbi,

Pastilles,

Arabic gum,

Gelatine

DOI:

https://doi.org/10.26656/fr.2017.4(2).319

\begin{abstract}
Pastille is a type of small round sweet confectionery product categorized in the Gummy Candies family that can be sucked or chewed. The goal of this research was to determine the physicochemical features and sensory profile of five pastille samples (F1, F2, F3, F4 and F5) produced with a mixture of belimbing buluh fruit juice and distinct concentrations of Arabic gum and gelatine. The pastilles were developed from the mixture of belimbing buluh fruit juice, sorbitol, sugar syrup using separate concentrations of Arabic gum $(0 \%$, $4 \%, 8 \%, 12 \%$ and $16 \%$ ) and gelatine. The physicochemical analysis shows that, F1 using $16 \%$ of gelatine obtained $19.48 \%$ moisture content, $0.25 \%$ crude fat, $20.60 \%$ crude protein, $0.45 \%$ crude fiber, $0.34 \%$ ash, $58.87 \%$ carbohydrates and $3475.3 \mathrm{kcal}$ calorie content, while F5 using 16\% of Arabic gum obtained 13.52\% moisture content, $0.688 \%$ crude fat, $0.69 \%$ crude protein, $0.188 \%$ crude fiber, $0.92 \%$ ash, $84.01 \%$ carbohydrates and $3174.1 \mathrm{kcal}$ calorie. The physical analysis showed that belimbing buluh fruit pastilles properties were influenced by the addition of Arabic gum and gelatine. The sensory study showed that the overall acceptance for sensory analysis showed that sample F3 (3.87) and sample F5 (3.63) were moderately liked by the panellists. However, more effort is needed in order to improve the quality of the belimbing buluh fruit pastilles, using other ingredients.
\end{abstract}

\section{Introduction}

The sour taste of belimbing buluh fruit is used in the manufacturing of vinegar, wine, and pickles and in the preparing of Hindi recipes (de Lima et al., 2001). These belimbing buluh are known to contain high bioactive compounds such as alkaloids, saponins, terpenoids and flavonoids (Abdul Wahab et al., 2009). Studies have discovered that the fruit, flowers and leaves of belimbing buluh are helpful in food and medicine, which can be used to cure cough, beri-beri and bilia and to decrease obesity (Lim, 2012).

Despite having a large source of nutrients and being helpful in medicine, belimbing buluh readily deteriorates after its phase of maturity. This is because when subjected to environmental modifications, bioactive compounds in the belimbing buluh are comparatively volatile (Hasim, 2014). After the maturity phases, the colour, texture, and nutrients will degrade. A way to preserve the bioactive compound is required by developing a fresh product that can last longer and retain its quality through extended storage. Research on belimbing buluh has concentrated on its prospective use as natural preservatives in the cooking process and as a natural antibiotic medication because of its antimicrobial characteristics that will benefit the user (Aziz, 2016). The abundance of belimbing buluh production and harvest year after year has led in enormous surplus and, except for cooking, actual use has rendered it a good potential commodity for creating products such as pastilles, so new study needs to be done by creating belimbing buluh-based pastilles to use this commodity.

Arabic gum a complex polysaccharide which consist of the mixture of the potassium, calcium and magnesium salt that are polysaccharidic acid (Ahmed et al., 2009) and branch chain that can be found in acidic or neutral (Ali et al., 2009). Arabic gum are widely used in food industries as the stabilizer, emulsifier, thickener and encapsulating (Azzaoui et al., 2014). Confectionary product such as pastilles and gummy mostly used Arabic 
gum for mouth feel and body (Dauqan and Abdullah, 2013). Gelatine is a gelling and forming agent that will produce a good food product character such as melt in the mouth due to its various setting temperature. Usually, gelatine are being used in a combination for confectionary product such as with Arabic gum and pectin (Edwards, 2000). William and Phillips (2003) stated that combination of Arabic gum and gelatine produced good texture, sensory acceptance and also can cut the cost of production.

Pastille is one of the confectionery products categorized in the gummy candies family (Lubbers and Guichard, 2003). Pastille leathery texture is perhaps the result of the gelling agent such as gelatine, starch and pectin. Gelatine is a significant component in pastille making that is used to add to the pastille texture and structure. The chewy texture of the pastilles is essential for consumers to enjoy. The texture of the pastilles also contributes to the aroma and flavour of the pastille product1. In pastille manufacturing, a large part of sugar or the combination between sugar and gelatine (Pothu and Yamsani, 2014) is often integrated, where it acts as a textured agent and stabilizer.

Until now, not many studies have been carried out on the use of belimbing buluh in pastille manufacturing. The utilization of belimbing buluh together with Arabic gum and gelatine could lead to increased pastilles quality and sensorial acceptance. The aim of this research was therefore to assess the impact of adding Arabic gum and gelatine with belimbing buluh on the physicochemical quality of pastilles, such as physical features, texture profile, proximate evaluation, and sensory properties.

\section{Materials and methods}

\subsection{Materials}

The raw materials needed for the study was the second stage of belimbing buluh's green hue of maturity. The half-ripen buluh of Belimbing was acquired from Pasar Batu Enam, Kuala Terengganu. Natural Prebiotic Sdn was provided with Tayebat ${ }^{\circledR}$ Arabic gum (96\% purity). Bhd.

\subsection{Preparation of pastilles}

Light green belimbing buluh fruits were chosen, sorted, washed and sliced into parts and put over the water tub for steaming at low temperature at $60 \mathrm{rpm}$ for 3 mins and cool with icy cold water to inactivate the enzyme prior to puree production. The sample was crushed, grind and filtered using a muslin cloth (DeMars and Ziegler, 2001). In the various formulations of the pastilles, the amount of belimbing buluh puree was kept constant. The quantity of Arabic gum and gelatine used varied among the various pastille formulations (Table 1). The solution of sorbitol, glucose syrup and Arabic gum was mixed in a pot and cooked and permitted to cool at $75^{\circ} \mathrm{C}$. Arabic gum solution $\left(25^{\circ} \mathrm{C}\right)$ was then added and blended into the solution of sorbitol-glucose syrup. At a mixing temperature of $75-80^{\circ} \mathrm{C}$, gelatine and maize flour were then added. The puree was added into the mixture at the last stage of cooking $\left(50-55^{\circ} \mathrm{C}\right)$. The cooked mixture was cooled to room temperature and citric acid was then added to bring the $\mathrm{pH}$ of the mixture down to 3.5. Lastly, the mixture was deposited in the starch mould and stove in the dehydrator at $46^{\circ} \mathrm{C}$ for $16 \mathrm{hrs}$. In order to form fruit pastilles, the final product was covered with fine sugar.

Table 1. Formulations for fruit pastilles production

\begin{tabular}{lccccc}
\hline \multirow{2}{*}{ Ingredients } & \multicolumn{5}{c}{ Formulation (\%) } \\
\cline { 2 - 6 } & F1 & F2 & F3 & F4 & F5 \\
\hline Glucose syrup & 23 & 23 & 23 & 23 & 23 \\
Sorbitol & 10 & 10 & 10 & 10 & 10 \\
Gelatine & 16 & 12 & 8 & 4 & 0 \\
Arabic gum & 0 & 4 & 8 & 12 & 16 \\
Citric acid & 0.5 & 0.5 & 0.5 & 0.5 & 0.5 \\
Corn flour & 0.5 & 0.5 & 0.5 & 0.5 & 0.5 \\
Belimbing buluh juice & 50 & 50 & 50 & 50 & 50 \\
Total & 100 & 100 & 100 & 100 & 100 \\
\hline
\end{tabular}

\subsection{Pastille proximate composition}

Proximate analysis was conducted to determine the percentage of moisture, ash, crude protein, crude fat, and crude fiber, according to the Association of Official Analytical Chemists' procedure (Baeza et al., 2010).

\subsection{Water activity}

Water activity $\left(\mathrm{A}_{\mathrm{w}}\right)$ was determined using a meter of water activity (Model: AquaLab Cx-2, England)(Baeza et al., 2010). The sample was prepared by cutting into tiny parts belimbing buluh fruit pastilles. Approximately $2 \mathrm{~g}$ of the sample was put in the water activity meter sample holder. The value of water activity was identified and reported. Triplicate sample reading was performed to obtain the precise value of fruit pastille water activity.

\subsection{Colour analysis}

The colour of pastille samples was determine using a chromameter (Minolta Chroma Meter CR 300, Japan), according to the CIE $\mathrm{L}^{*} \mathrm{a}^{*} \mathrm{~b}^{*}$ scale. The pastilles sample was placed into the platform where UV light and standard illuminate type $\mathrm{D}_{56}$ was used for the light penetration test using chromameter. Each sample was evaluated in triplicate separately.

\subsection{Pastille texture}

The instrumental texture measurements were made 
with a TA.XT.Plus texture analyzer (Stable Microsystems, UK). The hardness, springiness, chewiness and gumminess of the pastilles' product were determined by this assessment. A force-time graph was produced and textural parameters such as hardness, springiness, chewiness and gumminess were acquired with the assistance of the software supplied with the instrument.

\subsection{Melting point $\left(T_{m}\right)$}

Differential scanning calorimetry (DSC) was performed using a Microcal VPDSC (GE Healthcare). The DSC instrument was used to measure heat absorbed or liberated during heating or cooling. Approximately $10 \mathrm{mg}$ of the inner layer of sample was cut into small size. The samples were heating from $-40-120^{\circ} \mathrm{C}$ at $10^{\circ} \mathrm{C} /$ min and cool to $-40^{\circ} \mathrm{C}$ at $5^{\circ} \mathrm{C} / \mathrm{min}$. Then, heated again to $120^{\circ} \mathrm{C}$ at $10^{\circ} \mathrm{C} / \mathrm{min}$. Each sample took $74 \mathrm{~min}$ to run the analysis. The peak of the sample was then analysed (Hartel et al., 2011).

\subsection{Sensory evaluation}

Organoleptic preference of the products was carried out using 40 untrained panellists, recruited from staff and students of the School of Food Science and Technology, UMT. Product attributes, such as colour, aroma, taste, texture, and overall acceptance, were evaluated using a 7 -point hedonic scale from 1 to 7 ( 1 - dislike extremely, 2 - dislike very much, 3 - like slightly, 4 - neither like or dislike, 6 - like very much, 7 - like extremely) (Mau et al., 2017). The sample was packed and coded with a 3digit code. The coded samples were served in a tray to the panellist (Lawless and Heymann, 2010).

\subsection{Statistical analysis}

The data was collected and analysed using one-way variance (ANOVA) with multiple comparisons and the significant difference $(p<0.05)$ data were further analysed using Fisher's test at 95\% confidence intervals. The data were analysed using Minitab 14 software and all data obtained were presented at mean \pm standard deviation (Wasnin et al., 2012).

\section{Results and discussion}

\subsection{Proximate analysis}

The lowest moisture content was discovered in F5, whereas the highest moisture content was found in F1 (Table 2). The high value of the moisture content of belimbing buluh fruit pastilles in F1 may be due to the greater gelatine content. F5 incorporated greater amounts of Arabic gum with reduced moisture content owing to its reduced viscosity, making it low in moisture content (Azzaoui et al., 2014). The data also showed that the highest protein content of belimbing buluh fruit pastilles was found in F1, while the lowest protein content was found in F5. The amount of protein is contributed by the presence of Arabic gum as F1 is made of the highest amount of gelatine compared to other samples. Burey and co-workers (2009) mentioned that gelatine is high in protein content that comes from bones and skins of animals. Fiber content in the pastille samples was not significantly affected by the formulation used. Prasetyowati and co-workers (Prasetyowati et al., 2014) stated that there were significantly different $(p<0.05)$ in the addition of Arabic gum amount on the crude fiber in carrot and 'wortel' fruit leather. Table 2 also shows that the highest crude fat value was found in F5 while the lowest crude fat content was F3. The data express an increasing amount of Arabic gum and decreasing gelatine and fat content in the formulation of belimbing buluh fruit pastilles. This data is in accordance with the study by Azzaoui et al. (2014) who mention that there is no fat in gelatine and a low amount of fat in Arabic gum.

The lowest carbohydrates content for belimbing buluh fruit pastilles which was found in F1, while the highest carbohydrate content was observed in F5. According to William and Phillips (2003), Arabic gum have complex carbohydrates from A. senegal consist of arabinofuranose $(\sim 25 \%)$, rhamnopyranose $(\sim 14 \%)$, glucuropyranosyl uronic acid $(\sim 15.5 \%)$ and 4-O methyl glucuropyranosyl uronic acid $(\sim 1.5 \%)$. The ash content of pastilles made of gelatine and Arabic gum as the base to bind the mixture together forming the pastilles. The data also revealed that the lowest ash content was found in F1, while the highest content of ash content was found in F4. The addition of Arabic gum was significantly

Table 2. Proximate composition and DPPH radical scavenging activity of belimbing buluh fruit pastilles

\begin{tabular}{cccccccc}
\hline & Moisture (\%) & Fat (\%) & Protein (\%) & Fiber (\%) & Ash (\%) & Carbohydrate (\%) & DPPH (\%) \\
\hline F1 & $19.48 \pm 0.09^{\mathrm{a}}$ & $0.25 \pm 0.02^{\mathrm{b}}$ & $20.60 \pm 1.47^{\mathrm{a}}$ & $0.45 \pm 0.12^{\mathrm{a}}$ & $0.34 \pm 0.01^{\mathrm{c}}$ & $58.87 \pm 1.51^{\mathrm{d}}$ & $25.06 \pm 2.08^{\mathrm{a}}$ \\
F2 & $19.35 \pm 0.44^{\mathrm{a}}$ & $0.10 \pm 0.01^{\mathrm{c}}$ & $18.97 \pm 0.21^{\mathrm{a}}$ & $0.22 \pm 0.20^{\mathrm{ab}}$ & $0.48 \pm 0.04^{\mathrm{b}}$ & $60.88 \pm 0.48^{\mathrm{d}}$ & $25.26 \pm 1.29^{\mathrm{b}}$ \\
F3 & $18.26 \pm 0.29^{\mathrm{a}}$ & $0.03 \pm 0.01^{\mathrm{d}}$ & $12.84 \pm 0.76^{\mathrm{b}}$ & $0.12 \pm 0.02^{\mathrm{b}}$ & $0.87 \pm 0.03^{\mathrm{a}}$ & $67.88 \pm 0.99^{\mathrm{c}}$ & $20.97 \pm 1.33^{\mathrm{b}}$ \\
F4 & $15.66 \pm 0.01^{\mathrm{b}}$ & $0.23 \pm 0.01^{\mathrm{b}}$ & $5.92 \pm 0.37^{\mathrm{c}}$ & $0.21 \pm 0.08^{\mathrm{ab}}$ & $0.95 \pm 0.03^{\mathrm{a}}$ & $77.09 \pm 0.54^{\mathrm{b}}$ & $21.65 \pm 0.11^{\mathrm{b}}$ \\
F5 & $13.52 \pm 1.06^{\mathrm{c}}$ & $0.69 \pm 0.03^{\mathrm{a}}$ & $0.69 \pm 0.04^{\mathrm{d}}$ & $0.19 \pm 0.03^{\mathrm{ab}}$ & $0.92 \pm 0.08^{\mathrm{a}}$ & $84.01 \pm 0.92^{\mathrm{a}}$ & $36.52 \pm 1.20^{\mathrm{a}}$ \\
\hline
\end{tabular}

Different superscript letter indicates significant difference $(\mathrm{p}<0.05)$ within column. $\mathrm{F} 1=(0 \%$ Arabic gum, $16 \%$ gelatine $)$, F2 $=$ (4\% Arabic gum, $12 \%$ gelatine $), \mathrm{F} 3=(8 \%$ Arabic gum $8 \%$ gelatine $), \mathrm{F} 4=(12 \%$ Arabic gum, $4 \%$ gelatine $), \mathrm{F} 5=(16 \%$ Arabic gum, $0 \%$ gelatine) 
increased $(\mathrm{p}<0.05)$ the ash content in F4. This is might be due to the fact that Arabic gum possesses less than $4 \%$ of ash which is higher than gelatine that contains only $2 \%$ of ash (Burey et al., 2009).

\subsection{Antioxidative activity}

Table 2 also reveals that sample F5 exhibited the largest scavenging activity $(\mathrm{p}<0.05)$ compared to that of samples F1, F2, F3 and F4. The addition of Arabic gum in the blend was considerably impacted $(p<0.05)$ by the scavenging activity in belimbing buluh fruit pastilles. A study by Gallego and co-workers (2016) mention that gelatine could exhibit high antioxidant activity via the inactivation of free radicals by either migration of antioxidant molecules or scavenging of those oxidant molecules from the food product. Reducing colour from violet to light yellow or clear white colour occurs because of the ability of the antioxidant to scavenge the DPPH radical by forming DPPH-H through donating of hydrogen ion. Thus, hydrogen ion donation is capable of reducing violet colour to the solution's light yellow or white colour in F5.

\subsection{Texture profile analysis}

Table 3 shows the texture profile of the belimbing buluh fruit pastille samples prepared contain gum Arabic and gelatine combinations. The results showed that no significant difference for hardness values between samples F2 and F3, and also for samples F4 and F5. On the other hand, $F 1$ was significantly different $(p<0.05)$ with all other samples. F1 was prepared using a higher amount of gelatine indicates a higher value of hardness. The addition of gelatine in belimbing buluh fruit pastilles significantly affect $(\mathrm{p}<0.05)$ the hardness of $\mathrm{F} 1$ sample. The mixture of glucose syrup and gelatine made F1 sample harder compared to other formulation. Hardness could also be dependent on the sugar, water, gelatine, Arabic gum and dehydration process (Delgado and Bañón, 2015).

The addition of Arabic gum was significantly affected by the gumminess of F2, F3, and F4. F5 was lower in the water activity and hardness, thus the texture of the fruit pastilles was higher in gumminess compared to other formulations. Furthermore, F1 indicates higher gumminess value because too much gelatine content made the mixture high in viscous, thus influence high gumminess in F1 (Herbstreith and Fox, 2004). The chewiness attribute with the addition of Arabic gum on F2 was significantly affected the chewiness of the belimbing buluh fruit pastilles. Fontana (2005) stated that higher water activity in confectionery contributed to the chewy and smooth texture. In addition, decreasing of gelatine concentration tends to reduce the chewiness in the product. Arabic gum plays an important role where too much Arabic gum percentage contributed to a softer and less chewy texture.

\subsection{Melting point $\left(T_{m}\right)$}

Table 3 also shows the melting point of five fruit pastille formulations. Fruit pastille melting point ranged from $52.81^{\circ} \mathrm{C}$ to $102.76^{\circ} \mathrm{C}$. Sample F5 $\left(102.76^{\circ} \mathrm{C}\right)$ showed the highest melting point showing the impact of Arabic gum with a melting point of more than $250^{\circ} \mathrm{C}$. In addition, gelatine has low-temperature characteristics like melts (Fontana, 2005) and a melting point of $37^{\circ} \mathrm{C}$ (Schroder, 2003). In addition, the junction zone in gelatine is bind by the weak hydrogen bond, thus resulted in the low melting point compared to Arabic gum. According to Šmídová and co-worker (2004), the addition of flavour capable of influencing the physical characteristics of the product as flavour molecules may have caught in the amorphous matrix prior to moisture sorption and may have adequate flexibility to diffuse out of the matrix, which could lead to products becoming softer. The research also demonstrates that reduced moisture content suggests a greater melting point to break down carbohydrate molecules in fruit pastilles from glucose syrup, gelatine, Arabic gum and sorbitol. As the proportion of Arabic gum increased, the fruit pastille melting point also improved.

\subsection{Colour profile analysis}

Table 4 shows the colour profile analysis describing the lightness $\left(\mathrm{L}^{*}\right)$, yellowness $\left(\mathrm{a}^{*}\right)$ and redness $\left(\mathrm{b}^{*}\right)$ values of the belimbing buluh fruit pastilles containing different concentrations of Arabic gum and gelatine. The lightness value became lighter when more wheat Arabic

Table 3. Texture profile and physical analysis results of belimbing buluh fruit pastilles

\begin{tabular}{ccccccc}
\hline Sample & Hardness $(\mathrm{g})$ & Springiness $(\mathrm{mm})$ & Gumminess $(\mathrm{g})$ & Weight $(\mathrm{g})$ & Height $(\mathrm{mm})$ & Melting point $\left(\mathrm{T}_{\mathrm{m}}\right)$ \\
\hline F1 & $5801.84 \pm 471^{\mathrm{a}}$ & $0.98 \pm 0.01^{\mathrm{a}}$ & $5688.13 \pm 88^{\mathrm{a}}$ & $1.83 \pm 0.05^{\mathrm{a}}$ & $7.73 \pm 0.97^{\mathrm{a}}$ & $57.55 \pm 0.35^{\mathrm{b}}$ \\
F2 & $5093.23 \pm 60^{\mathrm{b}}$ & $0.97 \pm 0.02^{\mathrm{a}}$ & $3498.65 \pm 238^{\mathrm{c}}$ & $1.88 \pm 0.06^{\mathrm{a}}$ & $8.00 \pm 1.12^{\mathrm{a}}$ & $57.19 \pm 0.83^{\mathrm{b}}$ \\
F3 & $4693.04 \pm 196^{\mathrm{b}}$ & $0.94 \pm 0.01^{\mathrm{b}}$ & $4372.16 \pm 22^{\mathrm{b}}$ & $1.93 \pm 0.04^{\mathrm{a}}$ & $8.10 \pm 1.25^{\mathrm{a}}$ & $53.75 \pm 0.13^{\mathrm{bc}}$ \\
F4 & $2808.02 \pm 154^{\mathrm{c}}$ & $0.77 \pm 0.02^{\mathrm{d}}$ & $2169.49 \pm 19^{\mathrm{d}}$ & $1.99 \pm 0.03^{\mathrm{a}}$ & $8.12 \pm 1.54^{\mathrm{a}}$ & $52.81 \pm 0.66^{\mathrm{c}}$ \\
F5 & $2289.47 \pm 127^{\mathrm{c}}$ & $0.82 \pm 0.03^{\mathrm{c}}$ & $5667.42 \pm 85^{\mathrm{a}}$ & $2.04 \pm 0.04^{\mathrm{a}}$ & $8.18 \pm 1.68^{\mathrm{a}}$ & $102.76 \pm 1.15^{\mathrm{a}}$ \\
\hline
\end{tabular}

$\mathrm{F} 1=(0 \%$ Arabic gum, $16 \%$ gelatine $), \mathrm{F} 2=(4 \%$ Arabic gum, $12 \%$ gelatine $), \mathrm{F} 3=(8 \%$ Arabic gum, $8 \%$ gelatine $), \mathrm{F} 4=(12 \%$ Arabic gum, $4 \%$ gelatine $), F 5=(16 \%$ Arabic gum, $0 \%$ gelatine $)$ 
gum was used in the pastilles. The result proved that there were significantly different $(\mathrm{p}<0.05)$ between the formulation of fruit pastilles except for F2 and F3 and between F1 and F5. Similar values of $a^{*}$ and $b^{*}$ were recorded in all pastilles indicating the substitution of Arabic gum and gelatine did affect the colour characteristic of the samples. It is because, the colour of Arabic gum and gelatine was light yellow (Rahayu, 2013) and belimbing buluh juice was green in colour (Al -ruqaie et al., 1997). When gelatine and Arabic gum were added in the mixture of the sorbitol-glucose syrup the colour was yellowish then, the mixture was added with belimbing buluh juice, and the colour of the mixture was yellowish-green. For this purpose, the Arabic gum content did not influence pastilles colour, where a ${ }^{*}$ and $\mathrm{b} *$ were recorded similarly between samples.

Table 4. Effect of Arabic Gum and gelatine on the colour of belimbing buluh pastilles.

\begin{tabular}{cccc}
\hline Sample & $\mathrm{L}^{*}$ & $\mathrm{a}^{*}$ & $\mathrm{~b}^{*}$ \\
\hline F1 & $53.76 \pm 0.63^{\mathrm{b}}$ & $-1.02 \pm 0.02^{\mathrm{e}}$ & $12.89 \pm 0.4^{\mathrm{a}}$ \\
F2 & $48.60 \pm 0.68^{\mathrm{c}}$ & $-0.35 \pm 0.02^{\mathrm{c}}$ & $12.12 \pm 0.04^{\mathrm{b}}$ \\
F3 & $49.58 \pm 0.59^{\mathrm{c}}$ & $-0.15 \pm 0.01^{\mathrm{a}}$ & $11.51 \pm 0.17^{\mathrm{b}}$ \\
F4 & $65.37 \pm 1.23^{\mathrm{a}}$ & $-0.22 \pm 0.02^{\mathrm{b}}$ & $10.94 \pm 0.28^{\mathrm{b}}$ \\
F5 & $54.44 \pm 0.93^{\mathrm{b}}$ & $-0.52 \pm 0.02^{\mathrm{d}}$ & $10.86 \pm 0.20^{\mathrm{b}}$ \\
\hline
\end{tabular}

$\mathrm{n}=3$. Different superscript letter indicates significant difference $(\mathrm{p}<0.05)$ within column. $\mathrm{F} 1=(0 \%$ Arabic gum, $16 \%$ gelatine $), \mathrm{F} 2=(4 \%$ Arabic gum, $12 \%$ gelatine $), \mathrm{F} 3=(8 \%$ Arabic gum, $8 \%$ gelatine $), \mathrm{F} 4=(12 \%$ Arabic gum, $4 \%$ gelatine $), \mathrm{F} 5=(16 \%$ Arabic gum, $0 \%$ gelatine $)$

\subsection{Sensory evaluation}

Five sensory attributes, namely colour, aroma, taste, texture, and overall acceptability, were evaluated. Table 5 illustrates the means value of the acceptance test of belimbing buluh fruit pastilles made from Arabic gum and gelatine as the base of the formulation. Regarding the appearance characteristics, F3 had the highest score for colour, while F4 received the lowest score for this attribute. Table 5 also indicates that for hardness acceptance, sample F5 had the highest score for colour; whereas, F1 received the lowest score for this attribute. Texture profile analysis was used to support the outcomes from the sensory evaluation on the hardness acceptance showing that the hardness of the F1 was higher compared to other samples, thus influence the acceptance result on the hardness evaluation by panellists. It was defined that panellist does not like the highest value of hardness in the fruit pastilles especially F1 with $5801.84 \mathrm{~g} \mathrm{~mm}$ (Table 3).

Sample F5 was found to exhibit the highest value of chewiness with $4693.25 \mathrm{~g} \mathrm{~mm}$, followed by F3, F4 and F2 that almost get same mean value as F5. It was defined that panellist does not like the chewiness in the fruit pastilles especially F1 with $5290.4 \mathrm{~g} \mathrm{~mm}$. F1 exhibited a high value for chewiness in the texture analysis yet low chewiness acceptance by panellist because too much gelatine in the formulation will result in tenderness and chewiness. There was no significant difference $(p>0.05)$ between the acceptance of sweetness in all formulations of belimbing buluh fruit pastilles. This result indicated that the addition of Arabic gum did not influence the sweetness acceptance of belimbing buluh fruit pastilles. No significant difference between F2, F3, F4 and F5 and no significant difference between F1, F2 and F4 for sourness acceptance of belimbing buluh fruit pastilles. F3 with $8 \%$ of gelatine and $8 \%$ of Arabic gum shows the higher value of sourness acceptance of means value. The overall acceptance of the belimbing buluh fruit pastilles varied between 1.7 and 3.87. Saha and Bhattacharya (2010) stated that the combination of gelatine and Arabic gum usually give a good combination in term of mouthfeel and acceptability in a product, especially in pastilles.

\section{Conclusion}

The study showed significant impacts on the physicochemical and organoleptic properties of the final products. The addition of gum Arabic and gelatine enhanced the appearance and acceptance of belimbing buluh pastille a valuable component in food production. The newly developed formulation had suitable characteristics for oral administration. Sensory evaluation results showed that pastilles develop using belimbing buluh fruits associated with Arabic gum and gelatine was successfully measured. Based on overall

Table 5. Results of sensory evaluation of belimbing buluh pastilles.

\begin{tabular}{ccccccc}
\hline Sample & Colour & Hardness & Chewiness & Sweetness & Sourness & Overall acceptance \\
\hline F1 & $4.17 \pm 1.64^{\mathrm{a}}$ & $2.47 \pm 1.55^{\mathrm{b}}$ & $1.63 \pm 1.19^{\mathrm{bc}}$ & $2.60 \pm 1.40^{\mathrm{a}}$ & $2.40 \pm 1.57^{\mathrm{b}}$ & $1.70 \pm 1.09^{\mathrm{c}}$ \\
F2 & $4.10 \pm 1.58^{\mathrm{a}}$ & $2.50 \pm 1.61^{\mathrm{b}}$ & $1.77 \pm 1.04^{\mathrm{b}}$ & $2.73 \pm 1.64^{\mathrm{a}}$ & $2.77 \pm 1.57^{\mathrm{ab}}$ & $2.10 \pm 1.21^{\mathrm{bc}}$ \\
F3 & $4.23 \pm 1.76^{\mathrm{a}}$ & $3.73 \pm 1.64^{\mathrm{ab}}$ & $3.37 \pm 1.67^{\mathrm{ab}}$ & $3.53 \pm 1.59^{\mathrm{a}}$ & $3.63 \pm 1.61^{\mathrm{a}}$ & $3.87 \pm 1.63^{\mathrm{a}}$ \\
F4 & $3.3 \pm 1.47^{\mathrm{a}}$ & $2.77 \pm 1.63^{\mathrm{b}}$ & $2.60 \pm 1.33^{\mathrm{b}}$ & $3.13 \pm 1.41^{\mathrm{a}}$ & $2.93 \pm 1.55^{\mathrm{ab}}$ & $2.80 \pm 1.38^{\mathrm{b}}$ \\
F5 & $4.0 \pm 1.41^{\mathrm{a}}$ & $4.23 \pm 1.36^{\mathrm{a}}$ & $3.97 \pm 1.69^{\mathrm{a}}$ & $3.43 \pm 1.38^{\mathrm{a}}$ & $3.50 \pm 1.43^{\mathrm{a}}$ & $3.63 \pm 1.47^{\mathrm{ab}}$ \\
\hline
\end{tabular}

$\mathrm{n}=40$. Different superscript letter indicates significant difference $(\mathrm{p}<0.05)$ within column. $\mathrm{F} 1=(0 \%$ Arabic gum, $16 \%$ gelatine $)$, $\mathrm{F} 2=(4 \%$ Arabic gum, $12 \%$ gelatine $), \mathrm{F} 3=(8 \%$ Arabic gum, $8 \%$ gelatine $), \mathrm{F} 4=(12 \%$ Arabic gum, $4 \%$ gelatine $), \mathrm{F} 5=(16 \%$ Arabic gum, $0 \%$ gelatine) 
acceptability showing that F3 and F5 were more acceptable in term of gumminess, sweetness, sourness and overall acceptability. Therefore, gum Arabic could be a potential natural ingredient for pastille production.

\section{Conflict of Interest}

The authors declare no conflict of interest.

\section{Acknowledgement}

The authors gratefully acknowledging the Lab staff of School of Food Science and Technology, Universiti Malaysia Terengganu for financing the project and the laboratory facilities as well as Natural Prebiotic Sdn. Bhd. for providing the Arabic gum.

\section{References}

Abdul Wahab, N.H., Abd Wahid, M.E., Taib, M, Wan Mohd Zain, W.Z. and Anwar, S.A. (2009) Phytochemical screening and antimicrobial efficacy of extracts from Averrhoa bilimbi (Oxalidaceace) fruits against human pathogenic bacteria. Pharmacognosy Journal, 1(1), 64-66.

Ahmed, S.E., Mohamad, B.E. and Karamalla, K.A. (2009). Analytical studies on the gum exude from Anoffeissus leiocarpus. Pakistan Journal of Nutrition, 8(6), 782-786. https://doi.org/10.3923/ pjn.2009.782.786

Ali, B.H., Ziada, A. and Blunden, G. (2009). Biological effects of Arabic gum: A review of some recent research. Food and Chemical Toxicology, 47(1), 18. https://doi.org/10.1016/j.fct.2008.07.001

Al-ruqaie, I.M., Kasapis, S. and Abeysekerab, R. (1997). Structural properties of pectin-gelatin gels. Part II : effect of sucrose/glucose syrup. Carbohydrate Polymers, 34(4), 309-321. https://doi.org/10.1016/ S0144-8617(97)00107-0

Aziz, N.A. (2016). A review of the antimicrobial properties of three selected underutilized fruits of Malaysia. International Journal of Pharmaceutical and Clinical Research, 8(9), 1278-1283.

Azzaoui, K., Hammouti, B., Lamhamdi, A., Mejdoubi, E. and Berrabah, M. (2014). The Arabic gum in the southern region of Morocco. Moroccan Journal of Chemistry, 3(1), 99-107.

Baeza, R., Perez, A.A., Sanches, V. and Zamora M.C. (2010). Evaluation of Norrish's equation for correlating the water activity of highly concentrated solutions of sugars, polyols, and polyethylene glycols. Food Biotechnology, 3(1), 87-92. https:// doi.org/10.1007/s11947-007-0052-8

Burey, P., Bhandari, B.R., Rutgers, R.P.G., Halley, P.J. and Torley, P.J. (2009). Confectionery Gels: A Review on Formulation, Rheological and Structural Aspects. International Journal of Food Properties, 12, 176-210. https:// doi.org/10.1080/10942910802223404

Dauqan, E. and Abdullah, A. (2013). Utilization of Arabic gum for industries and human health. American Journal of Applied Sciences, 10(10), 1270 -1279 . https://doi.org/10.3844/ ajassp.2013.1270.1279

de Lima, V., Galvao, L.A., Mélo de almeida, E. and Santos, L.D. (2001) Physiochemical charcteristics of Bilimbii (Averrhoa bilimbi L.). Revista Brasileira de Fruticultura, 23(2), 421-423. https:// doi.org/10.1590/S0100-29452001000200045

Delgado, P. and Bañón, S. (2015). Determining the minimum drying time of gummy confections based on their mechanical properties. CyTA - Journal of Food, 13(3), 329-335. https:// doi.org/10.1080/19476337.2014.974676

DeMars, L.L. and Ziegler, G.R. (2001). Texture and structure of gelatine/pectin based gummy confections. Food Hydrocolloids, 15, 643-653. https://doi.org/10.1016/S0268-005X(01)00044-3

Edwards, W.P. (2000). The science of sugar confectionery., p. 150. Cambridge, United Kingdom: Royal Society of Chemistry.

Ergun, R., Lietha, R. and Hartel, R.W. (2010). Moisture and shelf life in sugar confections. Critical Reviews in Food Science and Nutrition, 50(2), 162-192. https://doi.org/10.1080/10408390802248833

Fontana, A.J.Jr. (2005). Water activity for predicting quality and shelf life. The Manufacturing Confectioner. Retrieved from website: http:// www.gomc.com/firstpage/200511045.pdf

Gallego, M.G., Gordon, M.H., Segovia, F. and PablosMaría, P.A. (2016). Gelatine-based antioxidant packaging containing Caesalpinia decapetala and Tara as a coating for ground beef patties. Antioxidants, 5(2), $10 . \quad$ https://doi.org/10.3390/ antiox 5020010

Hartel, R.W., Ergun, R. and Vogel, S. (2011). Phase/ state transitions of confectionery sweeteners: thermodynamic and kinetic aspects. Comprehensive Reviews in Food Science and Food Safety, 10(1), 17 -32 . https://doi.org/10.1111/j.15414337.2010.00136.x

Hasim, N.B. (2014). Study on bioactive compound degradation from Belimbing Buluh (Averrhoa bilimbi). Malaysia: Universiti Malaysia Pahang, BSc. Thesis.

Herbstreith and Fox. (2004). Confectionery Gum and 
Jelly Products., p. 1-31. Nuremberg, Germany

Mau, J.-L., Lee, C.-C., Chen, Y.-P. and Lin, S.-D.

(2017). Physicochemical, antioxidant and sensory characteristics of chiffon cake prepared with black rice as replacement for wheat flour. LWT - Food Science and Technology, 75, 434-439. https:// doi.org/10.1016/j.lwt.2016.09.019

Lawless, H.T. and Heymann, H. (2010). Sensory evaluation of food: Principles and Practices., p. 1471. USA: Springer.

Lim, T.K. (Ed.) (2012). Xanthophyllum amoenum. In Edible medicinal and non-medicinal plants. $1^{\text {st }}$ ed., p. 452. New York: Springer. https:// doi.org/10.1007/978-94-007-5653-3_23

Lubbers, S. and Guichard, E. (2003). The effect of sugars and pectin on flavour release from a fruit pastille model system. Food Chemistry, 81(2), 269-273. https://doi.org/10.1016/S0308-8146(02)00422-3

Pothu, R. and Yamsani, M.R. (2014). Lozenges Formulation and Evaluation: a Review. International Journal of Advances in Pharmaceutics Research, 5 (5), 290-298.

Prasetyowati, D.A., Widowati, E. and Nursiwi, A. (2014). The effect of Arabic gum addition to physicochemical and sensory properties of pineapple (Ananas comosus L. Merr). Jurnal Teknologi Pertanian, 15(2), 139-148.

Rahayu, P. (2013). Konsentrasi hambat minimum (KHM) buah Belimbing wuluh (Averrhoa bilimbi L.) terhadap pertumbuhan Candida albicans. Journal of Chemical Information and Modeling, 53(9), 16891699.

Saha, D. and Bhattacharya, S. (2010). Hydrocolloids as thickening and gelling agents in food: A critical review. Journal of Food Science and Technology, 47 (6), 587-597. https://doi.org/10.1007/s13197-0100162-6

Schroder, M.J.A (2003). Introduction. In Food quality and consumer value: Delivering food that satisfies. Heidelberg, Berlin: Springer. https:// doi.org/10.1007/978-3-662-07283-7_1

Šmídová, I., Čopíková, J., Maryška, M. and Coimbra, M. (2004). Crystals in hard candies. Czech Journal of Food Sciences, 21(5), 185-191. https:// doi.org/10.17221/3497-CJFS

Wasnin, R.M., Karim, M.S.A. and Ghazali, H.M. (2012). Effect of temperature-controlled fermentation on physico-chemical properties and lactic acid bacterial count of durian (Durio zibethinus Murr.) pulp. Journal of Food Science and Technology, 51(11), 2977-2989. https://doi.org/10.1007/s13197-0120869-7
William, P.A. and Phillips, G.O. (2003). Gums. Properties of Individual Gums. Society. In Caballero, E. (Ed.) Encyclopedia of Food Sciences and Nutrition. $2^{\text {nd }}$ ed., p. 2992-3001. USA: Academic Press. $\quad$ https://doi.org/10.1016/B0-12-227055$\mathrm{X} / 00573-3$ 